\title{
ロービジョン講習会による職員の意識変化について
}

本多 聖子・石井 祐子・南雲幹

若倉 雅登・井上 治郎

井上眼科病院

\section{Encouragement to hospital workers by education programs for low vision}

\author{
Minako Honda, Yuko Ishii, Miki Nagumo \\ Masato Wakakura, Jiro Inouye \\ Inouye Eye Hospital
}

要 約

目的：当院では「目の相談室」を設置し、ロービジョンケアに取り組んでいる。その取り組みの 中で「目の相談室」に直接関わるスタッフだけでなく、院内のすべての職員がロービジョンケアに 理解と関心を持つ必要があると考え、ロービジョン講習会（以下、講習会）を行った。

対象：平成13年 9 月から平成14年 9 月の期間に行った講習会に参加した、当院の様々な職種に携 わる職員104名である。

方法：講習会は、(1)ロービジョン者の心理についての講義、(2)誘導法のデモンストレーション、 (3)シミュレーションゴーグルを使用したロービジョンの疑似体験、を一回のプログラムとして行い、 後日、記名式でアンケート調査を行った。

結果：ロービジョン者誘導能力の自己評価は「できる」「だいたいできる」が講習会の前後で $54 \%$ 向上した。また、講習会に参加したことは業務に「役立つ」の回答が85\%、「少し役立つ」との回 答も含め $98 \%$ 至った。講習会参加後、「ロービジョン者に対する意識は変化したか」については 90\%以上が「変わった」「ある程度変わった」と回答した。

結論：ロービジョン講習会は、参加した職員のロービジョンケアへの理解を深めることができ、 ロービジョン者に対する意識の向上を図ることがでるものであった。講習会継続と職員への事後調 査は、意識変化を持続させるために重要であり、ロービジョンケアをより実践的で効果的なものと することができると考えられる。

別冊請求先（广101-0062）東京都千代田区神田駿河台 $4-3$

医療法人社団済安堂 井上眼科病院 本 多 聖 子

Tel. 03-3295-0937 (小児眼科外来) Fax. 03-5280-0270

Key words : Low vision, Simulation, Simulation goggle, Education program

$$
\text { ロービジョン, シミュレーション, シミュレーションゴーグル, 院内講習会 }
$$




\begin{abstract}
Purpose: Our hospital established "Consulting Room for Eyes," and since then we have been working on the programs for low vision care. We conducted the education program in order to make all the workers at the hospital aware of the importance of understanding low vision care.

Participants: One hundred and four workers from various sections at our hospital attended all the education programs for low vision care conducted form September 2001 to September 2002.

Method: Education program was conducted covering the points below.

1. Study of the low vision patients' psychology.

2. Demonstration of how to guide the patients.

3. Simulation of low vision wearing simulation goggles.

After program, all participants were asked to fill out a questionnaire with their signatures on.

Result: Self-evaluation on low vision aids has improved by $54 \%$. Almost all of them appreciated those programs were useful for their daily hospital jobs. Furthermore, more than $90 \%$ of all the participants have claimed that the program changed somewhat their views on low vision patients.

Conclusion: It is recognized that the program of this kind may encouraged participants to have a better understanding and awareness of low vision care. We conclude that continuous education program and research for our hospital workers is important to maintain the awareness and will make low vision care more practical and efficient.
\end{abstract}

\section{I．緒言}

井上眼科病院（以下、当院）では、平成11年 11月より、「目の相談室」を設置し、ロービジ ヨンケアに取り組んでいる。眼科にはさまざま な程度のロービジョン者が来院しているが、彼 らが通院や受診に少なからず困難を感じている ことが、この取り組みの中で明らかとなった。 そして眼科専門病院としての立場からロービジ ヨンケアには病院をあげて対応すべきである ${ }^{11}$ と考えるに至った。そこで、直接「目の相談室」 や診療に携わる医師、ソーシャルワーカー、看 護師、視能訓練士だけでなく、院内のすべての 職員が、ロービジョンに対して理解と関心を持 ち、ロービジョンケアへの意識を高める目的で、 ロービジョンケア講習会 (以下、講習会) を行 った。この試みの成果を知るため、講習会後に 行ったアンケート結果から職員の意識変化を報 告する。

\section{II. 対象及び方法}

対象は、平成13年 9 月から平成14年 9 月の期 間に 7 回行った院内ロービジョンケア講習会に 参加した当院の職員 (以下、参加者)、男性 20 名、女性84名、平均年齢33.8歳 (21～66歳)、平 均勤続年数 7.8 年（1 年未満～ 27 年）104名（全 職員の約 3 分の 1 ) であった。内訳は、検査 47 名、看護師16名、受付13名、医師11名、事務 11 名、薬剂師 3 名、栄養 2 名、施設 1 名で、様々 な職種に携わる者が参加するように配慮した。

講習会は、1 回に約16名を対象とし、(1)ロー ビジョン者の心理についての講義、(2)誘導法の デモンストレーション、(3)シミュレーションゴ ーグルを使用した、様々な動作項目からなるロ ービジョンの疑似体験、を 1 回のプログラムと して約 2 時間かけて行った。その後記名式のア ンケート（表 1 ）を配布、後日回収した。講習 会の内容について以下に記載する。

(1)ロービジョン者の心理について

最初に、「ロービジョン」とは、どのような ことなのかという説明を行い、次に、このよう 
1）以前から「ロービジョン」について知っていた。

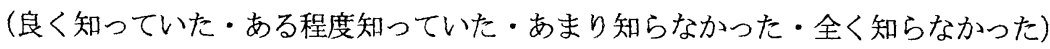

2）講習会に参加して、以前よりロービジョンの人の心理・見え方について理解できたと思いますか?

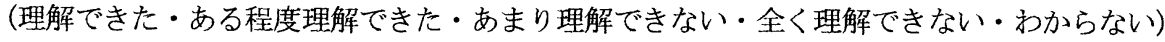

3）体験してみて難しかったものにO印を、やらなくても良いと思うものに×印をつけて下さい。 歩いてみる・階段（上り）・階段（下り）・エレベーター・自動ドア・自動販売機・コイン拾い 新聞（雑誌）を読む・問診表への記入・字を書く・視力検査・電話（携帯）をかける

4）上記の他に体験してみたい項目はありますか?（

5）今まで、自分は患者さんをちゃんと誘導できていたと思いますか？

（誘導できていた・大体できていた・あまりできていない・全くできていない・わからない）

6）講習を受けて、今後は安全に誘導ができると思いますか?

（できると思う・たぶんできる・たぶんできない・できないと思う・わからない）

7）今の病院の施設·設備はロービジョンの方に対して問題があると思いますか?

(ある・少しある・あまりない・まったくない・わからない)

8）7)で「ある」「少しある」と答えた方へ 具体的にどのようなところでしょうか？

9）今の病院職員の患者さんへの対応はロービジョンの方に対して問題があると思いますか? (ある・少しある・あまりない・まったくない・わからない)

10）9)で「ある」「少しある」と答えた方へ 具体的にどのようなところでしょうか?

11）講習会に参加したことは、仕事に役立つと思いますか?

（役立つ・少し役立つ・あまり役立たない・全く役立たない・わからない）

12）11）で「役立つ・少し役立つ」とした方へそれはどのようにですか?

13）ロービジョン講習会は、自分以外のスタッフにも受けて欲しいと思いますか?

(思う・少し思う・あまり思わない・全く思わない・わからない)

15）患者さんに対する考え方（意識）は以前と比べて変わりましたか?

（変わった・ある程度変わった・あまり変わらない・全く変わらない・わからない）

16）今後もロービジョンケアについて勉強してみたいと思いますか?

(思う・少し思う・あまり思わない・全く思わない・わからない) 
表 2 視覚障害が患者さんの心理、生活、人生にもたらす影響について

$$
\text { (『ロービジョンハンドブック』より抜粋し、要約) }
$$

\section{1）身体的完全性の缞失}

視覚障害者になったことで、今までとは違い完全な人間ではないと感し、自分の価値や社会で役割を果 たすこと、人と対等に競う能力に疑問を持つようになります。

\section{2）残された感覚に対する自信の齐失}

視覚が障害され、他の感覚からの情報を再確認する能力を失うと、ロービジョン者は感覚による判断 に不安を持つようになります。

\section{3）移動能力の衰失}

乗り物の行き先表示、料金表・時刻表や時計が見えにくくなり、歩道の段差や階段、信号も見えにく くなり道路を単独で歩行することが危険になるため、家に閉じこもってしまう傾向があります。

\section{4）日常生活技術の丧失}

食事、調理、爪切り、化粧など日常の些細な行動にも不都合が生じ、買い物、お金（紙幣・硬貨）の 見分け・支払い、電話をかける、サインをする等、一つ一つが時間と努力を要するものとなります。

5）文字によるコミュニケーション能力の喪失

文字を読む能力が低下して、新䦥や手紙、仕事の書類を読むこともできなくなります。また、きれい に文字を書けなくなり、書けても自分の書いた文字を読み返すことができなくなります。

6）会話によるコミュニケーション能力の齐失

話している相手の顔の表情や身振りを観察するという、コミュニケーションで重要な部分が失われる ため言葉だけで意味を判断せざるをえなくなってしまい、誤解が生じる可能性が大きくなります。

\section{7）楽しみを感じる力の壊失}

視覚障害になって最もつらいのは、愛する人たちの顔が見られなくなることです。また、思い出のあ る写真やスポーツ、ゲーム、裁縫、映画鑑賞、TVを見ることなどの多くが困難になってしまうのです。

\section{8）職業、就労の機会の丧失（経洧的安定の襄失）}

それまでしてきた仕事で役割を果たす能力を失うと、努力して得てきたもののほとんどを失い、収入 がなくなってしまいます。自己の能力への評価は下がり、自分を無用の存在と感じ、落ち込んでしま う人がほとんどです。これは青年期・壮年期に視觉障害になった人にとって、深刻な閔題といえます。

9）個人としての独立心の壊失

日常の行動が不自由であるとわかると、家族や友人が、患者の自立を回復させようとせず、かえって 世話を焼くようになり、患者の依存度を高めてしまうことがあります。

10)一般的な存在であることの喪失

家族、友人、社会からそれまでと異なる扱い方をされるようになり、「視覚障害者」である自分は哀れ みを受ける存在であると感じ、社会からの隔㕍、疎外感を感じるようになります。 
なロービジョン者の存在が社会的に認知されて いないこと、また、そのために彼らがどのよう なことに心理的ストレスや、物理的な不自由を 感じているのかも一般には知られていないこと を、駅で切符を購入する例を挙げて説明した。 その後に、人生の中途から視覚障害になること によって生じる変化について理解を深めてもら うことを意四して、『ロービジョンハンドブッ ク』(梁島謙次監訳) から抜粋、要約した「口 ービジョンとなることにより心理的・社会的に 喪失するもの」²について、10項目（表 2 ）に まとめた資料を一人一項目ずつ音読してもらっ た。講義の最後には、眼科の病気は治療をして も視覚に障害が残ってしまうもの、治療法がな い進行性のものがたくさんあり、このあとのシ ミュレーションを通し、視覚に障害のある患者 さんの苦労・痛み・悲しさ・諦め·苛立ち・不 安といった様々な気持ちを理解して、眼科で働 く職員（人）としてできることはどのようなこ となのか、ひとりひとりに考えて欲しいと結ん だ。

\section{(2)誘導法のデモンストレーション}

基本的な誘導法として、通常歩行・狭いとこ ろでの歩行・階段昇降の誘導・いすへの誘導な ど数種をデモンストレーションしてみせた。

(3)シミュレーションゴーグルを装用してのロー ビジョン体験（図 1)

二人一組になり、交代で一人がシミュレーシ ヨンゴーグルを装用し、もう一人が基本的な誘 導法を踏まえて介助者となり、あらかじめリス トアップした動作（12項目）を体験した。各組 には、「目の相談室」で研修を受けた看護師か 視能訓練士が一人付き添い、安全面にも配虑し、 状況に応じてアドバイスしながら行った。シミ ユレーションゴーグル（以下、ゴーグル）は、 Zimmerman社製Low Vision Simulation Kits ${ }^{\circledR}$ (図 2 ) を視野狭窄、白内障、屈折異常のそれぞ れ程度を変えて組み合わせ、表 3 の 4 種の条件 に改変して使用した。

ゴーグルは任意で選択し、おおむね一種類を 使用したが、希望により複数試した者もいた。 今回は、ゴーグルの.条件ごとの比較は行ってい ない。

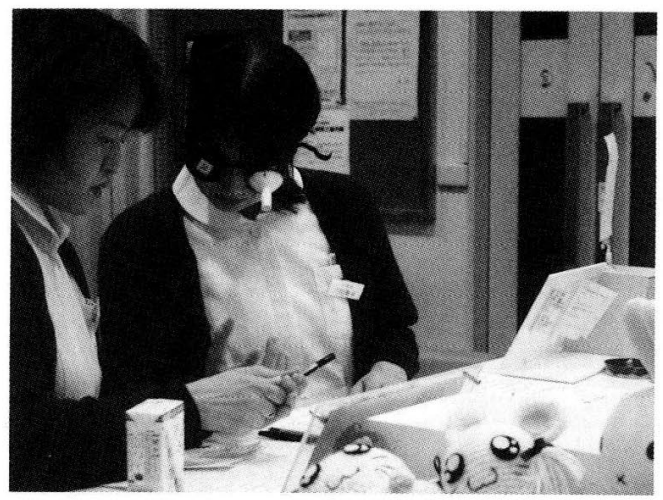

A．問診表の記入

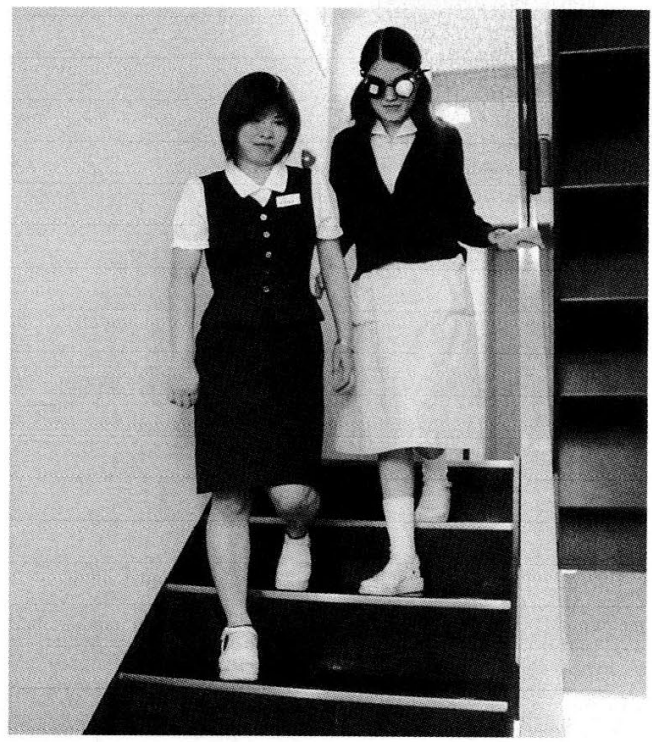

B．階段を降りる

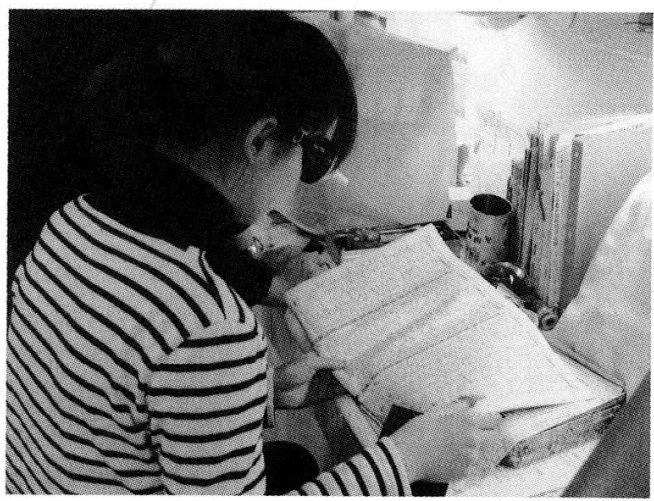

C. 新聞を読む

図 1 シミュレーションゴーグルを装用してのロー ビジョン体験 


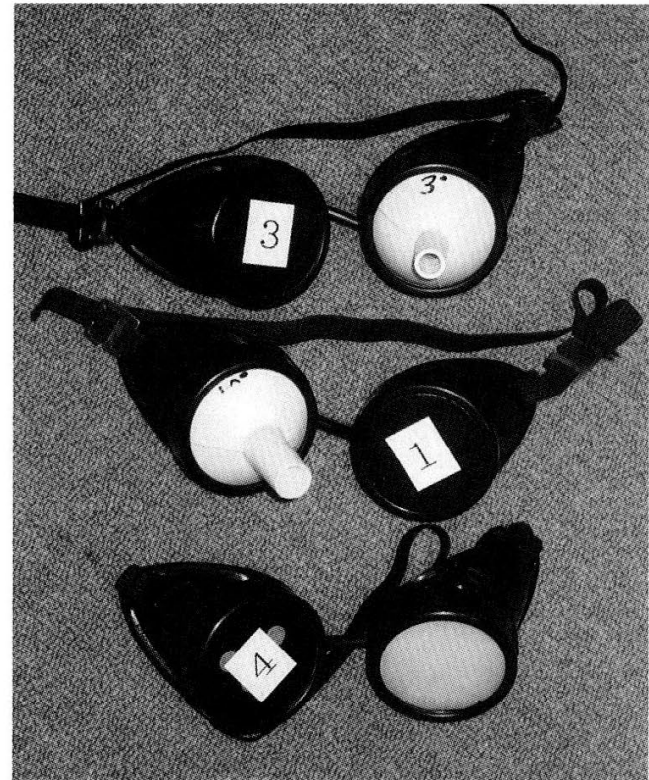

図 2 Zimmerman社製 シミュレーションゴーグル

表 3 シミュレーションゴーグルの条件

\begin{tabular}{|l|c|c|c|}
\hline & 視野 & 白内障 & 屈折異常 \\
\hline NO.1 & 10 度 & 軽度 & あり \\
\hline NO.2 & 7度 & 重度 & あり \\
\hline NO.3 & 3度 & 軽度 & なし \\
\hline NO.4 & 正常 & 重度 & あり \\
\hline
\end{tabular}

\section{III. 結 果}

講習会参加前、ロービジョンについて「よく 知っていた」 $4 \%$ 、「ある程度知っていた」 56\%であった（図 3 )。

シミュレーションで難しかったと感じた動作 を複数回答で多い順に示す（図 4 )。「階段を降 りる」 $(82.7 \%) 「$ 自動販売機」 $(57.7 \%) 「$ 「階段を 昇る」(51.0\%) で、「すべて」の項目に難しか ったと回答した者が12.5\%であった。

講習会で行った以外に体験してみたい動作は、 交通機関の利用、駅から病院までの過程、悪天 候、日没後の屋外歩行、診察室や検查室の出入 り、食事や化粧、パソコンを使う、買い物をす る、などであった。

ロービジョン者誘導能力の自己評価を講習会 の前後について比較した（図 5 )。講習前につ いて、自分はロービジョン者の誘導が「できる」

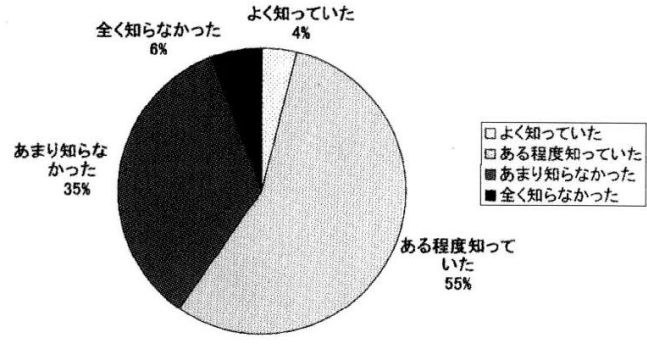

図 3 職員の予備知識程度

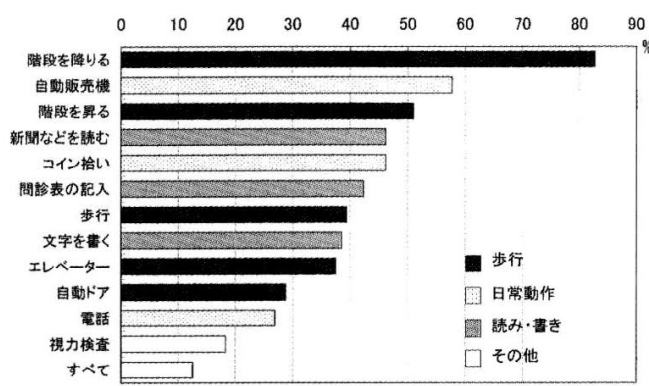

図 4 体験して難しかったこと

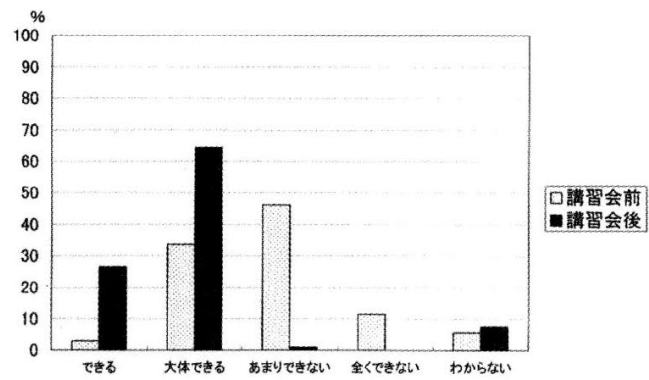

図 5 ロービジョン者誘導能力の自己評価

及び「だいたいできる」と思う、が37\%であった が、講㱛会後には91\%になり、逆に「あまりでき ない」「全くできない」と思う、は58\%から $1 \%$ \%った。

施設接遇に関して、「当院の現状に問題がある か」についての回答結果を図 6 に示す。施設 「ある」「少しある」85\%、接遇「ある」「少し ある」59\%と多数であり、一方、施設接遇面共 に問題が「まったくない」の回答は $0 \%$ \%゙った。 具体的には、施設「狭い」「暗い」「表示が見にく い」「段差が多い」「ドアと通路の境目がわかりに くい」患者さんの移動が多い」接遇「安全面や 効率に気をとられて心理面の対応におよんでい 

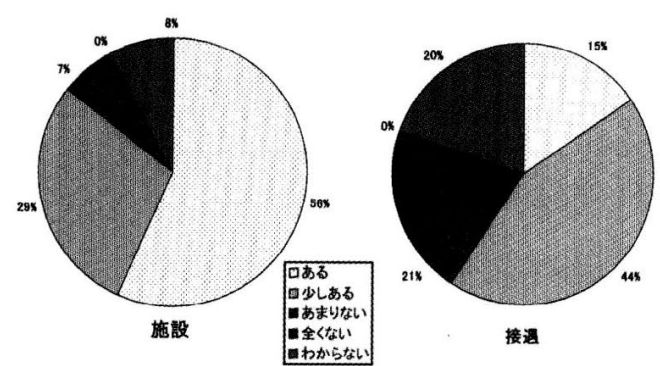

図 6 問題意識 $(\mathrm{a}$, 施設 $\mathrm{b}$, 接遇)

ない。」「積極性が足りない。」「気持ちはあっても 忙しさで行き届かない。」などであった。

「講習会に参加したことは、自分の業務の役に 立つと思うか」については、85\%が役立つ」と回 答し、「少し役立つ」も含めると $98 \%$ に至った (図 7 )。また、「この講習会を他の職員にも受
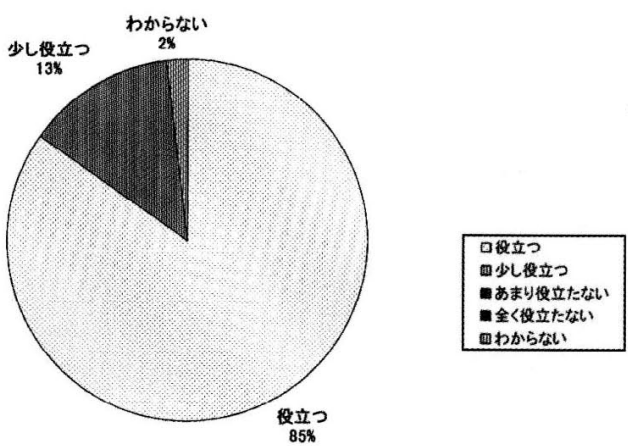

図 7 業務への役立ち

けてほしいと思うか」については、「思う」が93\% で、「少し思う」も含めると100\%に及んだ。どの ように業務に反映させるか、具体的には、「会 計時に数人を続けて呼ばずに間をあけるように する。」「食事の際、盛り付け、食器でコントラス トをつける。」忠者さん向けの掲示物や印刷物、 予約票のフォントやレイアウトを工夫する。」 どがあがった。また、「具体的な行動や言葉か けだけではなく、ロービジョンを理解するとい うだけでも患者さん側の受ける印象が違ってく るのではないか。との記入もあった。

講習会参加後、「ロービジョン者に対する意識 は変化したか」については、90\%以上が「変わっ た」「ある程度変わった」と回答した（図 8 ）。
具体的には、以下のような記入がみられた。 「これからは安全面だけでなく、心理面も考えて 接遇にあたりたい。」「今までよりも、ロービジ ヨン者の立場に立って業務ができると思う。」 「誘導法を知って、声が掛けやすくなった。」 「予想していなかった動作に難しさを感じるもの があった。「自己流の接し方に問題があったこ とがわかった。「見えにくいということは、と てもストレスの溜まることだと思った。」

さらに、「今後もロービジョンケアについて勉 強したいと思うか」については、「思う」68\%で、 「少し思う」と合わせると $95 \%$ あった。（図 9）

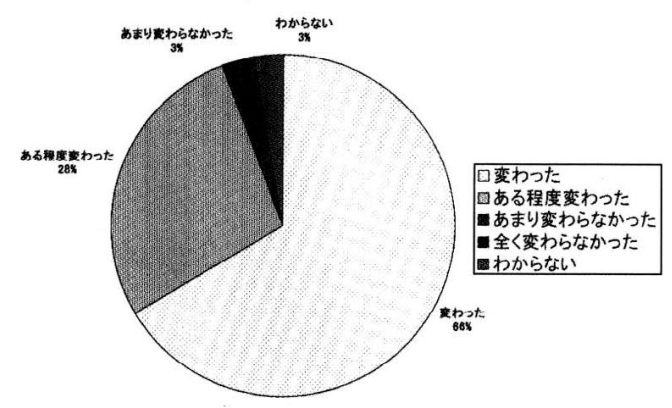

図 8 ロービジョンに対する意識の変化

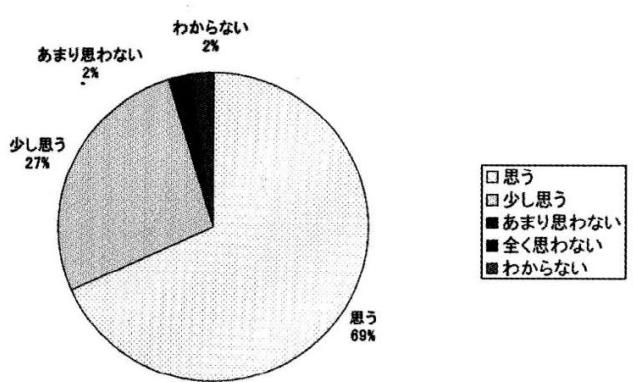

図 9 ロービジョンの勉強を続けたいか

\section{IV. 考按}

ロービジョンについての予備知識程度は職種 によって差があると思われるが、「ある程度の知 識」があるのは 6 割にとどまり、対象が眼科病院 の職員であるにもかかわらず、高いとは言えな かった。

実際に体験して難しかったと感じた動作につ 
いては、「階段の降り」が最も多く、「階段を上 る」よりも難しさを感じたのは、下りでは前方 に広い空間があるのに視覚の手がかりを失って いることから恐怖心を伴うためと考えられた。 「自動販売機」は、商品サンプルから飲み物を選 び、コインを投入し、飲み物を取り出して、ス トローを使って飲むという $1 つ 1 つ$ 異なる要素 の入る一連の動作であり、日常、無意識で連続 して行える動作がロービジョン者にとっては、 予想以上に困難で時間もかかるものだとわかる ものであった。「コイン拾い」は、床に散らばっ たコインを探して拾う動作であるが、視力低下 がなくとも高度な視野狭窄では、この動作は困 難が生じる。つまり、困難は視力低下だけで測 ることは出来ないことがわかる。「問診表の記 入」は、読字と書字が混在することで難しさを 感じる動作であったが、問診表記入だけでなく、 当然のように行っている自分の日常業務の見直 し (反省)、問題提起にもなった。「歩行」で は、日常業務で通り慣れた院内を歩くことにさ え、恐怖心や不自由を感じることが、やはり問 題提起になったと思われる。

体験してみたい動作は、業務に関連した通院、 受診の際の動線や日常動作などであった。参加 者が講習会で体験した経験から発展させた回答 である。

ロービジョン者誘導能力の自己評価について は、講習会で誘導法の基礎を学び、シミュレー ションしたことで講習会後、向上した。前記の 予備知識程度では「ある程度は理解していた」 の回答が半数以上であったにもかかわらず、受 講前に誘導について「できる」「だいたいでき る」は、 3 分の 1 程度と低く、誘導法は参加者 が知りたいという要望の多いものであったこと と符合する。

施設接遇の問題点の有無については、ロービ ジョン者の立場にたって院内をみなおして、気 づいたものである4)。施設 接遇面ともに多数回 答であり、「問題が全くない」の回答がないこ とからも参加者が、問題意識を持つ動機づけに なったと考えている ${ }^{5)}$ 。

こうしたことから、講習会の業務への役立ち を認め、他の職員も参加するべきとの回答は、
講習会に参加したことによって、ロービジョン ケアは特定の職種、職員だけが行う特別のもの ではなく、誰もが係わっていることであり、実 践できることがあり、自分を含めた多くの職員 がロービジョンについて理解する必要があるこ とを感じたといえる。業務への反映に具体的に 挙げられた記入は、各自が講習会で知り得たこ と、感じたことを業務と関連付けていかに生か すかを考えたものであることを表わしている。

そして講習会後にロービジョン者に対する意 識変化を多くの参加者にもたらすことができた のは、ロービジョンを知ることで、各自がぼん やりと持っていたにすぎなかったロービジョン 者のイメージを明確にし、そのロービジョン者 と各自の関わり方を見直すことができたためで ある。

眼科で仕事をする上で、直接的、間接的にか かわらず、ロービジョン者と無関係ではありえ ない。そのため、今回の講習会では、職種、予 備知識量を問わず、ロービジョンを理解する手 がかりとしてシミュレーションを用いた。この 方法ですべてを理解しうることは出来ないが ${ }^{6}$ 、 体験から実感することで関心を高め、意識を向 上させる役割を効果的に果たすことができた。 それは、今後もロービジョンの勉強を続けたい 旨の多くの回答につながり、積極的にロービジ ヨンケアに係わり、よりよいロービジョンケア を提供できる場としようとする姿勢に発展した と捕らえている。

しかし、この意識変化がどのように実践的に 反映されているかは未調査である。今後、講習 会の継続によって職員全員の参加をすすめてい くことで意識変化を広めるとともに、更なる講 習会や職員への事後調査を行うことは、意識変 化を持続させるために重要であり、ロービジョ ンケアをより実践的で効果的なものとすること ができると考えられる。

\section{参考文献}

1）木村 徹, 他：これからのコメディカルに期 待すること一眼科専門病院における教育の実 際一。あたらしい眼科 $15: 767-771,1998$. 
2）3）梁島謙次 監訳：ロービジョンハンドブ ック Barbara Brown著, 103-109, 診断 と治療社，東京，1999。

4 ) 雨宮恵美 : 眼科医院の職員に求められる仕事 の心構え一患者接遇への取り組みが仕事を変 えるー。あたらしい眼科 $15: 805-809$, 1998.
5 ）難波哲子，他：シミュレーションを利用した 視能矯正実習教育の試み。日視会誌 23 : 138-143， 1995.

6 ）梁島 謙次, 石田 みさ子 監訳：視覚のシミュ レーション. Randall T. Jose(編) : ロービジ ヨン理論と実践, $24-28$, 社会福祉法人日本 盲人福祉委員会，埼玉，1992. 